\title{
Perceptions of Father Involvement among Turkish Fathers with Pre-school Children
}

\author{
Kazım Biber \\ Correspondence: Kazım Biber, Necatibey Education Faculty, Balıkesir University, Turkey
}

Received: February 14, 2016 Accepted: March 14, 2016 Online Published: March 25, 2016

doi:10.11114/jets.v4i6.1376

URL: http://dx.doi.org/10.11114/jets.v4i6.1376

\begin{abstract}
The purpose of this study is to compare father involvement among fathers with children in pre-school in terms of their status of having only one or more than one child. The study sample consisted of fathers of 3-5 year-old children who were enrolled in pre-schools in the district of Alt1eylül, Balıkesir. Data pertaining to the involvement of fathers with one child and with more than one child were collected with the Father Involvement Scale (FIS) developed by Şendil and Simsık1 (2014). Data was collected from a total of 325 fathers and Confirmatory Factor Analysis (CFA) was performed to test the construct validity of the FIS. The data derived from the Father Involvement Scale were collected in three sub-dimensions: DI (Discretionary Involvement), BC (Basic Care), RC (Responsiveness and Closeness), and were analyzed using hierarchical regression analysis. The results of the research revealed that the number of children had an impact on the discretionary involvement and responsiveness and closeness dimensions of father involvement and that fathers with only one child had higher levels of perception of the role of fatherhood and also higher levels of household task involvement compared to fathers with two or more children. According to these results, since a positive perception of the role of fatherhood is strongly and positively associated with family involvement activities, educators may provide support in enabling fathers and other family members to develop a positive perception of fatherhood. In providing this support, to avoid the differences stemming from the variable of being a father of a single child or of more than one child, planning activities together with fathers to provide real-life examples that promote time management and effective leisure time management may encourage fathers to spend more quality time with their children.
\end{abstract}

Keywords: fatherhood, father involvement, single child, multiple child, family involvement

\section{Introduction}

The quality of education provided in the pre-school period is directly related to how much the individuals that are in closest interaction with the child can support the process of education. The family is the first and closest group that characteristically carries the capability of being an educational resource in this period of the child's development. Achieving permanent behavioral changes in children at the pre-school level may be made possible only if the learning experiences planned in the school curriculum are followed up and continued in the family environment (Aral, Baran, Bulut, Çimen, 2000). Working to involve families in education and teaching during the pre-school period yields positive outcomes in terms of many aspects of education, including developing pupils' behavioral and social adjustment, reducing disciplinary issues in the school environment, increasing pupils' school attendance and academic achievement, and ensuring that students acquire more social skills (Kotaman, 2008). In addition, making a family education program and family involvement a part of education will make what is learned at the pre-school level continuously effective throughout the student's life (Hohman and Weikart, 2000).

\subsection{Father Involvement}

Family involvement efforts that seek to include both mothers and fathers in school activities are of great importance. It is a fact however that over the years, family participation in school activities was usually considered the predominant involvement of mothers. This was because the father figure in the traditional family was perceived very differently from the mother. In the traditional form of family, the father is seen as the family member that is responsible for providing the family with economic support and authority. The mother, on the other hand, is the person to be most directly involved in a child's care and education (Tezel and Özbay, 2009). When mothers are perceived as primarily responsible for the child's education, fathers are more likely to take on the duty of providing the child with financial support (Riley et al., 2000). The active involvement of fathers in their children's education became to be more widely noticed as of the 1970's and fathers 
participating in school activities together with their children began to be accepted as a customary practice. With the advancement of technology, education, politics, science and industry, it became more readily understood that the role of the father in a child's development was as important as the role of the child's mother (Çatıkkaş, 2008). In response to changing social conditions and the evolving expectations of society from fathers, research began to reveal that the effective participation of fathers in the education of their children had a positive impact on the child's development (McBride and Lutz, 2004; McBride et al., 2004). Additionally, the increasing inclusion of women in the workforce changed fathers' roles to a significant degree and fathers realized the necessity of training themselves to be as effective in the household, in childcare and education, as the women in the family. Together with this, an increasing emphasis on the identity of a father and the importance of fathers as a role model in bringing up a child led to a rising interest on the part of fathers to become involved in their children's educational process (Gürşimşek et al., 2007).

When Allen and Daily's (2002) investigation into father involvement in education is studied, it can be seen that the researchers reached the conclusion that when fathers become involved in educational activities, their children's attitudes toward school becomes more positive and they spend more of an effort to succeed at school and participate in social events. The researchers report that the warm and supporting attitude of fathers toward their children has a significant impact on the children's being able to learn the moral values of the society in which they live. From a different perspective, teachers find the opportunity to become more acquainted with children's families when fathers are involved in the education and teaching process; teachers try to understand the father's point of view and become more sensitive toward the expectations of the family (Carter, 2003). Fagan and Iglesias (1999), in a study in which they conducted a pre-school family involvement activity where fathers were included, found that the children whose fathers had participated in the school activity displayed an improvement in their mathematical skills (as cited in Green, 2003). When fathers engage in warm relations with their children and actively participate in their education, the self-confidence of their children grows, they achieve a better academic performance, and they form healthier relations with their peers, display a healthier development in terms of gender roles and are better able to make use of economic resources (Green, 2001).

\subsection{Factors that Affect Father Involvement}

Research has shown that fathers with a higher educational background are better able to adapt to the role of participating in their children's school activities. Although education and income are closely associated, they have not been found to affect a father's involvement in the same way. While men with higher levels of education are more likely to participate in household duties, men with high incomes participate less (Model, 1981). Because of the higher quality of work that an educated father engages in and since higher paying jobs are more time-consuming, this leaves the father less time to become involved (Harris \& Morgan, 1991). In another study, it was found that African-American fathers read to their children less but spend more time playing with them compared to other American fathers (Green, 2003; Halle and le Menestral, 1999).

Levine (1993) described the factors that act as barriers to father involvement in family involvement programs organized in the early childhood years. These were fathers' fears of incompetence, the approach to father involvement of the program-organizing experts, mother-related barriers, and inappropriate program setups and applications. It was reported that father involvement rates in family involvement activities would increase if these obstacles could be overcome. In another study in which levels of father involvement in pre-school education were investigated, it was found that in schools that did not encourage fathers to take part in school activities, fathers felt that they could not find the time to participate, they did not feel comfortable at school, they had difficulty in establishing relations with other parents and that they were also unwilling to participate because of these and other similar reasons (Gürşimşek, Kefi and Girgin, 2007).

The attitude of a father toward gender roles is one of the most important predictors of his participation in the care of his child (Radin and Goldsmith, 1989; Coverman, 1985). As the attitude toward gender roles takes on a more contemporary perspective, father involvement increases (McHale and Huston, 1984). Fathers who are more involved in their children's lives are fathers whose notion of fatherhood goes beyond supplying children with their economic needs and acting as a disciplinarian to encompassing a firm and close interest in the child and taking part in the child's care. Fathers' attitudes toward mothers' gender roles also influence fathers (Russell, 1978), and therefore father involvement is more pronounced among fathers that maintain non-traditional attitudes in this respect (Baruch and Barnett, 1981). Particularly when women work, fathers' attitudes toward male roles are of greater significance and men married to women with a liberal attitude are seen to participate more in childcare (Radin, 1981).

The father's age also has an influence on his involvement. It has been found that when more mature fathers come to a certain point in their careers, they are more likely to participate in their child's development compared to younger fathers (Marsiglio, 1993). The psychological characteristics of fathers are important factors that determine the quality of his parenting and the amount of his involvement (Grossmon, Pollack \& Golding, 1988). Fathers who are not anxious, who have a high degree of self-worth and are able to exercise self-control are more participatory in their child's development 
(Cowan \& Cowan, 1988). How a father perceives himself as a father, how comfortable he feels in this role (Levy-Shiff and Israelashvilli, 1988) and his perception of his own competence in childcare (McHale and Huston, 1984) all affect his involvement.

As for how the child's age affects a father's involvement, the finding is that the older the child, the more the father's participation increases. The tasks of changing diapers and bathing a baby are traditionally regarded as the mother's responsibilities. The care of older children, on the other hand, does not conflict with traditional roles and because the responsibilities in this context are less influenced by gender roles, father participation tends to increase, both in terms of taking on tasks alone and also in performing tasks in cooperation with the mother (Radin, 1981). The child's gender too affects involvement; a father is more apt to be involved with a son's life (Harris and Morgan, 1991). All through the infancy of the child, the father behaves more differently toward girls and boys than the child's mother does. It has been observed that fathers engage in direct physical contact with their boy babies more (Parke and O'Levy, 1976), provide boys with more stimulants (Parke, 1981), and communicate and play with them more (Marsiglio, 1991).

Research results reveal that father involvement is affected by factors related to fathers themselves, such as their attitudes toward gender roles, their psychological condition and their education, by factors related to the child's mother, such as her attitude toward gender roles, her employment status, the hours she works, and by factors concerning the child, such as age and gender. In the light of this, the present study aimed to investigate levels of father involvement among fathers of children of the ages 3-5 enrolled in pre-school programs, based on the fathers' own views and in terms of whether the fathers have one or more than one child.

\section{Method}

\subsection{Research Model}

The present study was carried out as descriptive research aiming to investigate levels of father involvement among fathers of children of the ages 3-5 enrolled in pre-school programs, based on the fathers' own views and in terms of whether the fathers have one or more than one child.

\subsection{Study Sample}

The study group in the research comprised the fathers of 325 children, ages 3-5, enrolled in independent public nursery schools operating in the District of Alteylül, Province of Balıkesir, District Directorate of National Education.

In terms of their ages, $13.5 \%$ of the fathers were below the age of $30,36.6 \%$ were between $31-35,31.6 \%$ were $36-40$ and $18.2 \%$ were over the age of 40 . Of the fathers, $5.8 \%$ were graduates of elementary school, $14.2 \%$ of middle school, $32.3 \%$ of high school; $42.2 \%$ were university graduates and $5.5 \%$ had graduate degrees. Of the fathers in the sample, $92.0 \%$ were employed and $8.0 \%$ were unemployed. A group of $35.3 \%$ of the fathers had a monthly income of between TL 750-1500 (approximately $\$ 300-\$ 600$ ), $38.4 \%$ an income of TL $1600-3000$, and $26.2 \%$ of over TL 3100 . Of the fathers comprising the sample, $2.8 \%$ were in a second marriage, $97.2 \%$ in a first marriage; $34.1 \%$ had been married for $0-7$ years, $57 \%$ for $8-15$ years and $8.9 \%$ for $16-25$ years. While $35.5 \%$ of the fathers had only one child, $64.5 \%$ were fathers of more than one child. Responding to the question about whether their child had any diagnosed chronic medical condition, $7.7 \%$ responded "Yes" and 92.3\% answered "No."

\subsection{Data Collection Instrument}

\subsubsection{Information Form}

This form, which was drawn up to compile demographic information about the fathers, consisted of eight multiple-choice and graded questions designed to collect the father's statements on his age, education, income level, employment status, number of marriages, their duration, whether there was one child or more than one in the family, and whether the child had any kind of chronic medical condition.

\subsubsection{The Father Involvement Scale (FIS)}

The Father Involvement Scale (FIS) is a scale that assesses the involvement of fathers who have children, ages 3-6. The Father Involvement Scale (FIS) developed by Şendil and Sımsıkı (2014) is made up of 37 items and three subscales. The Discretionary Involvement (DI) dimension has 17 items, the Responsiveness and Closeness (RC) 12 items, and the Basic Care (BC) dimension, 8 items. FIS items are arranged in the form of types of behavior and receive responses on the basis of a five-response Likert-type scale. The choice of "Always like this" receives 5 points, "Mostly like this" receives 4 points, "Sometimes like this" 3 points, "Rarely like this" 2 points and "Never like this" receives 1 point. Points are obtained as a total score and also as separate scores for each dimension. A father's high score on the scale indicates that his level of involvement is high.

Some of the statements on FIS are as follows: DI (Discretionary Involvement) I play vigorous games with my child. I play with my child's toys when I'm playing with him (truck, doll, etc.). I read to my child. I take my child to the park. BC (Basic 
Care) I take an interest in whether or not my child brushes his/her teeth. I comb my child's hair. I take an interest in my child's toilet training. I put my child to sleep at bedtime. RC (Responsiveness and Closeness) I take my child up on my lap. I'm interested in my child's health. I tell my child I love him/her. I try to calm my child down when $\mathrm{h} / \mathrm{she's} \mathrm{upset.} \mathrm{I}$ know what makes my child happy.

The results of the reliability analysis that Şendil and Sımsıkı (2014) performed in a study they conducted with 350 fathers whose children, ages 3-6, were enrolled in a pre-school revealed Cronbach alpha reliability coefficients of .89 for the Discretionary Involvement dimension, .83 for the Basic Care dimension, .85 for Responsiveness and Closeness and .92 for the FIS total score.

In the present study, the internal consistency coefficient for the Discretionary Involvement subscale of a total of 17 statements was found to be $\alpha=0.88$; the 8-statement Basic Care subscale displayed an internal consistency coefficient of $\alpha=0.82$, while the 12 -item Responsiveness and Closeness subscale's internal consistency coefficient was calculated as $\alpha=0.84$. These results indicate that the scores obtained from FIS are reliable.

\subsection{Data Collection and Analysis}

After the official permissions were obtained for the research, the researcher informed the administrators and teachers of a total of four public and independent pre-schools in the district of Alt1eylül, Balıkesir about the study. The researcher distributed a total of 375 measurement tools for the fathers to fill out but only 348 of the forms were returned. After incomplete and erroneously filled out instruments were eliminated, data were ultimately collected from 325 fathers for use in the study.

Data were collected from a total of 325 fathers and Confirmatory Factor Analysis (CFA) was performed to test the construct validity of the FIS. CFA was performed using the LISREL software, version 8.8 (Jöreskog and Sörbom, 2006). The recommended polychoric correlation matrix was created for the analysis of item level data in the Confirmatory Factory Analysis and the Diagonally Weighted Least Squares estimation technique was used.

The predictive effect of the independent variables in the research on the dependent variables was examined with a total of three hierarchical regression analyses. The hypotheses of the regression analysis were tested using graphs. In the hierarchical regression analysis, the independent variables were added into the regression model in one block in three steps. In the first step, age, education, income, employment status and similar demographic variables were added to the model. In the second step, marital variables such as civil status and the duration of marriage were added. In the last step, the variables of number of siblings, order of birth, and chronic illness were added to the model. The regression analysis was performed using SPSS, version 19.

\section{Results}

\subsection{Results of the Confirmatory Factor Analysis}

The results of the CFA showed that the 37-factor model consisting of a total of 37 items had acceptable fit indices and that the model was a good fit for the data $(\chi 2=1152.32, \mathrm{df}=626, p<.001$; RMSEA $=0.051, \% 90 \mathrm{GA}=0.046-0.56$; AGFI $=0.95$; $\mathrm{CFI}=0.98$, NNFI=0.98).

It was observed that the factor loads on the Discretionary Involvement subscale varied between 0.48 and 0.77 , that the factor loads on the Basic Care subscale varied between 0.53 and 0.74, and that the factor loads on the Responsiveness and Closeness subscale varied between 0.59 and 0.89 . The correlation coefficient between the Discretionary Involvement subscale and the Basic Care subscale was found to be 0.68, that between the Discretionary Involvement and Responsiveness and Closeness subscales was found to be 0.74 and that the correlation coefficient between the Basic Care subscale and the Responsiveness and Closeness subscale was 0.52. The factor loads and correlation coefficients between the factors in the Confirmatory Factor Analysis are shown in Figure 1. 


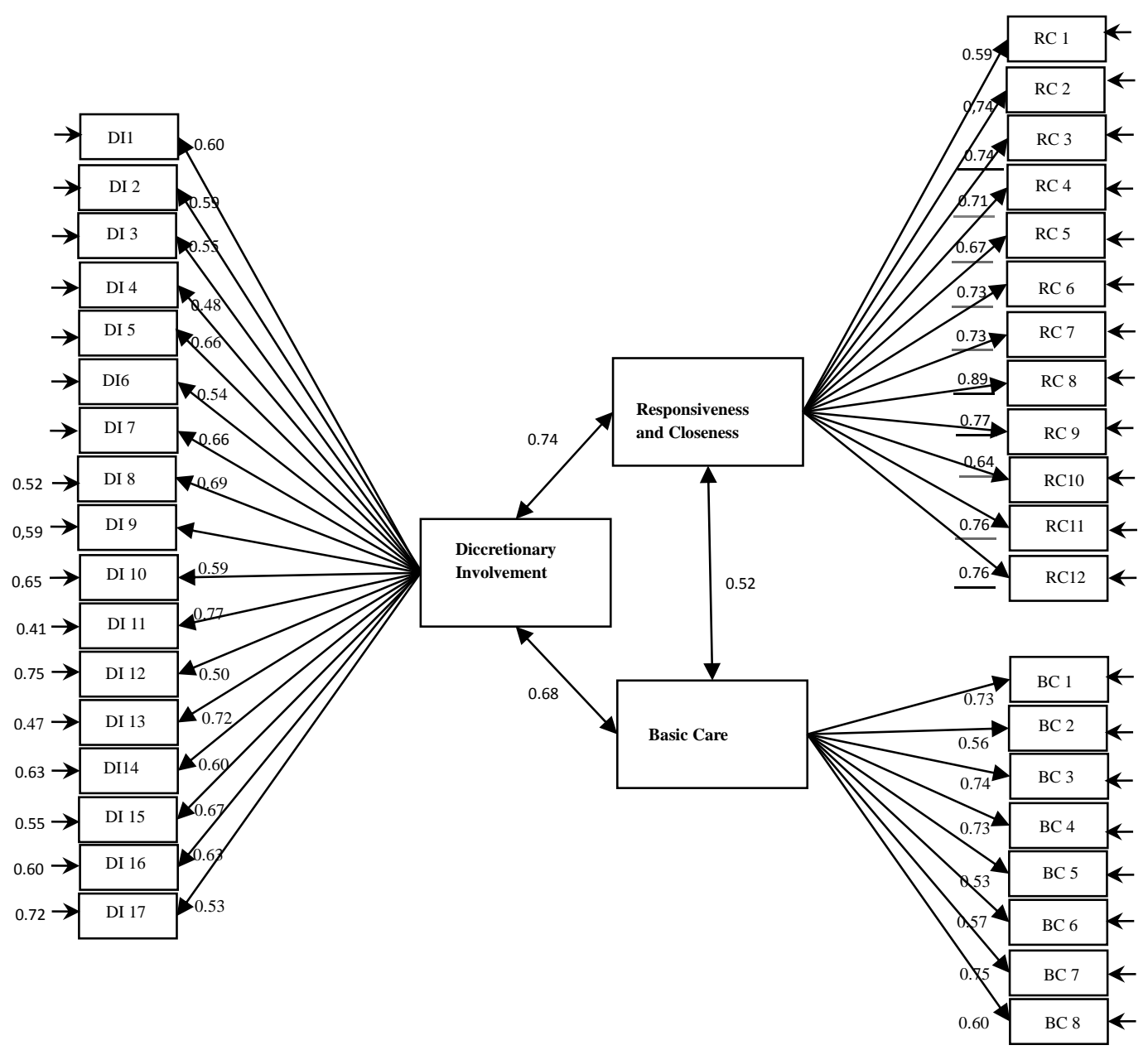

Figure 1. Factor loads and correlation coefficients between the factors in the Confirmatory Factor Analysis

\subsection{Hierarchical Regression Analysis}

In the first step of the hierarchical regression analysis to explore how much the dependent variable Discretionary Involvement could be predicted using the information in the independent variables, demographic variables such as age, education, income, employment status were entered into the equation and the results were found to explain $2.4 \%$ of total variance $\left(\mathrm{R}=.024, \mathrm{R}^{2}=.024, \mathrm{~F}(5,187)=10,570 p<.05\right)$; it was observed that only the education variable was a significant predictor of the Discretionary Involvement variable $(\beta=0.138, p=0.041)$. In the second step, the variables of civil status and the duration of marriage were additionally entered into the regression model of the first step. The added contribution of this was $0.6 \%$; this, together with the variables in the first step, raised explained variance related to basic care to $2.9 \%$ $\left(\mathrm{R}=.029, \mathrm{R}^{2}=.006, \mathrm{~F}(6,404)=7,998 p<.05\right)$ whereas the variables of civil status and duration of marriage that were entered into the regression model in the second step made no statistically significant contribution to the regression equation.

In the last step, the variables of number of siblings, birth order and chronic illness added to the regression model made a contribution of $5.1 \%$ to total variance, increasing explained variance related to basic care to $8.1 \%\left(\mathrm{R}=.081, \mathrm{R}^{2}=.051, \mathrm{~F}(6\right.$, $332)=7,914 p<.05)$. Only the number of siblings in the final step $(\beta=-0.288, p=0.001)$ was found to significantly predict the variable Discretionary Involvement. In the final model, the variable of education had lost its significance in the equation. The results show that as the number of siblings increase, discretionary involvement points tend to fall. The results of the hierarchical regression analysis related to the dependent variable Discretionary Involvement are shown in Table 1. 
Table 1. Results of Hierarchical Regression Analysis related to the Dependent Variable "Discretionary Involvement"

\begin{tabular}{|c|c|c|c|c|c|c|c|}
\hline \multirow{2}{*}{ Model } & \multicolumn{2}{|c|}{ Unstandardized } & Standardized & \multirow{2}{*}{$\mathrm{t}$} & \multirow{2}{*}{ Sig. } & \multirow{2}{*}{$\mathrm{R}^{2}$} & \multirow{2}{*}{$\Delta \mathrm{R}^{2}$} \\
\hline & B & Std. Error & Beta & & & & \\
\hline 1 st Step & & & & & .101 & .024 & .024 \\
\hline Constant & 54.825 & 5.187 & - & 10.570 & .000 & & \\
\hline Age & .018 & .121 & .009 & .151 & .880 & & \\
\hline Education & 1.597 & .777 & .138 & 2.055 & .041 & & \\
\hline Income & .000 & .000 & .028 & .413 & 680 & & \\
\hline Employment & -1.431 & 2.339 & -.035 & -.612 & .541 & & \\
\hline 2nd Step & & & & & 144 & .029 & .006 \\
\hline Constant & 51.218 & 6.404 & & 7.998 & .000 & & \\
\hline Age & .129 & .150 & .060 & .856 & .393 & & \\
\hline Education & 1.559 & .783 & .135 & 1.991 & .047 & & \\
\hline Income & .000 & .001 & .022 & .322 & .748 & & \\
\hline Employment & -1.711 & 2.366 & -.041 & -.723 & .470 & & \\
\hline Civil Status & 2.675 & 3.926 & .039 & .681 & .496 & & \\
\hline Marriage Duration & -.252 & .199 & -.089 & -1.269 & .205 & & \\
\hline 3rd Step & & & & & .002 & .081 & .051 \\
\hline Constant & 50.112 & 6.332 & & 7.914 & .000 & & \\
\hline Age & .115 & .149 & .054 & .770 & .442 & & \\
\hline Education & 1.353 & .767 & .117 & 1.763 & .079 & & \\
\hline Income & .000 & .000 & .037 & .556 & .579 & & \\
\hline Employment & -2.363 & 2.320 & -.057 & -1.018 & .309 & & \\
\hline Civil Status & 4.567 & 3.871 & .067 & 1.180 & .239 & & \\
\hline Marriage Duration & -.269 & .247 & -.095 & -1.088 & .277 & & \\
\hline Number of Siblings & -5.481 & 1.168 & -.288 & -3.838 & .000 & & \\
\hline Birth Order & 3.434 & 1.790 & .179 & 1.918 & .056 & & \\
\hline Chronic Illness & -4.447 & 2.316 & -.106 & -1.920 & .056 & & \\
\hline
\end{tabular}

In the first step of the hierarchical regression analysis to explore how much the dependent variable Basic Care could be predicted using the information in the independent variables, demographic variables such as age, education, income, employment status were entered into the equation and the results were found to explain $2.1 \%$ of total variance $\left(\mathrm{R}=.021, \mathrm{R}^{2}\right.$ $=.021, \mathrm{~F}(3,230)=10,165 p<.05)$; it was observed that only the employment variable was a significant predictor of the Basic Care variable $(\beta=-0.14, p=0.014)$. In the second step, the variables of civil status and the duration of marriage were additionally entered into the regression model of the first step. The added contribution of this was $0.2 \%$; this, together with the variables in the first step, raised explained variance related to basic care to $2.2 \%\left(\mathrm{R}=.022, \mathrm{R}^{2}=.002, \mathrm{~F}(3,996)=\right.$ $8,325 p<.05)$ and none of these made a statistically significant contribution to the equation. In the last step, it was seen that the variables of number of siblings, birth order and chronic illness that were added to the regression model made no significant contribution to the equation. In the final model, the variable of employment status continued to make a statistically significant contribution. It was ultimately found that the variable of the fathers' employment status was a significant predictor of their scores in the variable of basic care. In other words, fathers who were not employed were more likely to have higher scores on the basic care scale compared to fathers who were employed. The results of the hierarchical regression analysis related to the dependent variable Basic Care are shown in Table 2. 
Table 2. Results of Hierarchical Regression Analysis related to the Dependent Variable "Basic Care"

\begin{tabular}{|c|c|c|c|c|c|c|c|}
\hline \multirow{2}{*}{ Model } & \multicolumn{2}{|c|}{ Unstandardized } & Standardized & \multirow{2}{*}{$\mathrm{t}$} & \multirow{2}{*}{ Sig. } & \multirow{2}{*}{$\mathrm{R}^{2}$} & \multirow{2}{*}{$\Delta \mathrm{R}^{2}$} \\
\hline & B & Std. Error & Beta & & & & \\
\hline 1st Step & & & & & .148 & .021 & .021 \\
\hline Constant & 32.838 & 3.230 & & 10.165 & .000 & & \\
\hline Age & -.058 & .075 & -.044 & -.772 & .441 & & \\
\hline Education & .068 & .484 & .009 & .140 & .889 & & \\
\hline Income & .000 & .000 & .051 & .752 & .452 & & \\
\hline Employment & -3.604 & 1.457 & -.140 & -2.474 & .014 & & \\
\hline 2nd Step & & & & & .296 & .022 & .002 \\
\hline Constant & 33.279 & 3.996 & & 8.327 & .000 & & \\
\hline Age & -.098 & .094 & -.074 & -1.043 & .298 & & \\
\hline Education & .099 & .488 & .014 & .202 & .840 & & \\
\hline Income & .000 & .000 & .051 & .744 & .457 & & \\
\hline Employment & -3.588 & 1.477 & -.140 & -2.430 & .016 & & \\
\hline Civil Status & -.003 & 2.450 & .000 & -.001 & .999 & & \\
\hline Marriage Duration & .088 & .124 & .050 & .707 & .480 & & \\
\hline 3rd Step & & & & & .596 & .023 & .000 \\
\hline Constant & 33.078 & 4.059 & & 8.149 & .000 & & \\
\hline Age & -.095 & .095 & -.071 & -.994 & .321 & & \\
\hline Education & .086 & .492 & .012 & .176 & .861 & & \\
\hline Income & .000 & .000 & .052 & .747 & .455 & & \\
\hline Employment & -3.599 & 1.487 & -.140 & -2.420 & .016 & & \\
\hline Civil Status & .101 & 2.482 & .002 & .041 & .968 & & \\
\hline Marriage Duration & .064 & .158 & .036 & .401 & .689 & & \\
\hline Number of Siblings & -.111 & .748 & -.012 & -.149 & .882 & & \\
\hline Birth Order & .280 & 1.148 & .023 & .244 & .808 & & \\
\hline Chronic Illness & -.483 & 1.485 & -.018 & -.325 & .745 & & \\
\hline
\end{tabular}

In the first step of the hierarchical regression analysis to explore how much the dependent variable Responsiveness and Closeness could be predicted using the information in the independent variables, demographic variables such as age, education, income, employment status were entered into the equation and the results were found to explain 1.3\% of total variance but not to yield any significant relationship. In the second step, the variables of civil status and the duration of marriage were additionally entered into the regression model of the first step. The added contribution of this was $0.1 \%$; this, together with the variables in the first step, raised explained variance related to Responsiveness and Closeness to $1.5 \%$ but none of the variables made a statistically significant contribution to the equation. In the last step, the variables of number of siblings, birth order and chronic illness added to the regression model made a contribution of $0.5 \%$ to total variance, raising explained variance related to responsiveness and closeness to $6.4 \%$. Only the variables of chronic illness $(\beta=-.183, p=0.001)$ and number of siblings in the final step $(\beta=-2.7, p=0.007)$ were found to significantly predict the independent variable Responsiveness and Closeness. The results show that as the scores for chronic illness and number of siblings increased, the fathers' responsiveness and closeness points tended to fall. The results of the hierarchical regression analysis related to the dependent variable Responsiveness and Closeness are shown in Table 3. 
Table 3. Results of Hierarchical Regression Analysis related to the Dependent Variable "Responsiveness and Closeness"

\begin{tabular}{|c|c|c|c|c|c|c|c|}
\hline \multirow{2}{*}{ Model } & \multicolumn{2}{|c|}{ Unstandardized } & Standardized & \multirow{2}{*}{$\mathrm{t}$} & \multirow{2}{*}{ Sig. } & \multirow{2}{*}{$\mathrm{R}^{2}$} & \multirow{2}{*}{$\Delta \mathrm{R}^{2}$} \\
\hline & $\mathrm{B}$ & Std. Error & Beta & & & & \\
\hline 1st Step & & & & & .369 & .013 & .013 \\
\hline Constant & 53.004 & 2.108 & & 25.146 & .000 & & \\
\hline Age & .052 & .049 & .060 & 1.048 & .295 & & \\
\hline Education & .450 & .316 & .096 & 1.425 & .155 & & \\
\hline Income & .000 & .000 & -.113 & -1.653 & .099 & & \\
\hline Employment & .495 & .951 & .030 & .521 & .603 & & \\
\hline 2nd Step & & & & & .581 & .015 & .001 \\
\hline Constant & 52.038 & 2.608 & & 19.954 & .000 & & \\
\hline Age & .053 & .061 & .061 & .868 & .386 & & \\
\hline Education & .468 & .319 & .100 & 1.467 & .143 & & \\
\hline Income & .000 & .000 & -.119 & -1.720 & .086 & & \\
\hline Employment & .401 & .964 & .024 & .416 & 678 & & \\
\hline Civil Status & 1.061 & 1.599 & .038 & .664 & .507 & & \\
\hline Marriage Duration & -.007 & .081 & -.006 & -.087 & .930 & & \\
\hline 3rd Step & & & & & .012 & .064 & .050 \\
\hline Constant & 51.224 & 2.582 & & 19.839 & .000 & & \\
\hline Age & .065 & .061 & .076 & 1.077 & .282 & & \\
\hline Education & .384 & .313 & .082 & 1.226 & .221 & & \\
\hline Income & .000 & .000 & -.109 & -1.609 & 109 & & \\
\hline Employment & .211 & .946 & .013 & .223 & .824 & & \\
\hline Civil Status & 1.829 & 1.579 & .066 & 1.158 & .248 & & \\
\hline Marriage Duration & -.059 & .101 & -.052 & -.589 & .556 & & \\
\hline Number of Siblings & -1.286 & .476 & -.204 & -2.701 & .007 & & \\
\hline Birth Order & 1.266 & .730 & .163 & 1.735 & .084 & & \\
\hline Chronic Illness & -3.115 & .944 & -.183 & -3.298 & .001 & & \\
\hline
\end{tabular}

\section{Discussion}

Besides enjoying the support of a mother, a child's relations in future life are also significantly affected by the sense of worth instilled in the child by the father (Bowlby, 1982) and it is this concept of how having a caring, responsive father is just as important in child development as the presence of a caring and nurturing mother that makes this a matter that needs to be explored (Ainsworth et al., 1978; as cited in Easterbrooks and Goldberg, 1984).

To date researchers have explored the dimensions of father involvement in the context of selected activities, setting forth varied nomenclature in their studies (Pleck, 2010) and conducting more concentrated investigations into certain specific behavior (Cabrera et al., 2007). As explained by Palkovitz ( 2002) as well, because there is no conceptual framework on father involvement that can be converted into psychometrically valid and reliable measurements, the dimensions of father involvement have remained beyond the scope of standard measuring techniques.

In the present study, the predictive effect of independent variables on the dependent variables of discretionary involvement, basic care and responsiveness and closeness were examined with a total of three hierarchical regression analyses. In the hierarchical regression analysis, the independent variables were added into the regression model in one block in three steps. In the first step, age, education, income, employment status and similar demographic variables were added to the model. In the second step, marital variables such as civil status and the duration of marriage were added. In the last step, the variables of number of siblings, birth order and chronic illness were added to the model.

In the hierarchical regression analysis on the predictability of the dependent variable "Discretionary Involvement," it was seen that as the number of siblings increased, the fathers' discretionary involvement scores tended to decrease.

Paquette et al. (2000), Seçer et al. (2007) and Kuruçırak (2010) have reported that the rate of father involvement diminishes the more the number of children and that the perception of fatherhood in this case will change in a negative direction. These results suggest that fathers with only one child are likely to engage themselves more with their children because of the excitement of being a father for the first time but that as the number of children increases and the excitement of fatherhood fades, they might not be as much inclined to set aside adequate time for their children. Şahin and Demiriz (2014) have found that fathers with only one child have higher perceptions of their role as fathers and are more likely to participate in household activities, compared to fathers with two or more children. Simsıkı and Şendil (2014), in their investigation into the demographic variables related to father involvement, have reported that the mean scores of fathers with a single child are higher in the areas of discretionary involvement and on the total FIS compared to fathers with two or more children. Paquette, Bolte, Turcotte, Dubeau and Bouchard (2000) have found that the rate of father involvement diminishes as the number of children increases. Similarly, Mehall et al. (2009) have shown in the results of their work that as the number of siblings increase in a family, fathers tend to show less of an interest in their babies. On the other hand, the results of research by Ishii-Kuntz et al. (2004) and Hamamcı (2005) have indicated that parental feelings 
of adequacy and parental involvement with childcare will increase even more as the number of children in the family increases. This result may have stemmed from cultural differences in families and from demographic characteristics related to the variables in the study. Paulson et al. (2010) has asserted that the number of children in a family does not have a significant effect in this respect.

According to the results of the hierarchical regression analysis performed to determine the degree to which the information in independent variables can predict the dependent variable Basic Care in FIS, an instrument comprising activities that reflect direct contact, unemployed fathers are more likely to register higher scores in the basic care variable compared to fathers who work.

Poyraz (2007) has found that there is no significant difference in fathers' perceptions of their role as fathers when considered in terms of their professions but that the scores of the role of fatherhood among fathers who are employers and civil servants are higher than fathers in other occupations. The same research has made the point that working at a highly stressful and tiring job may have an adverse effect on fathers' perceptions of their fatherhood roles. Barling (1986) reports in a study that explores the relationship between a father's working conditions and children's behavior problems that in situations where fathers are not happy with the conditions of their jobs, their children will be more likely to be hyperactive and display problem behavior.

Mothers may be working in families where fathers are unemployed. Research has reported findings that show that father involvement is affected by the mother's working outside of the home as well as by the mother's working schedule (Coltrane, 1995; Radin and Harold-Goldsmith, 1989). Hoffman (1974) has reviewed studies on gender roles in families in which the woman works and has asserted that although fathers rarely take on childcare as a primary responsibility, they tend to be more actively involved in routine childcare when the spouse is a working mother.

In the study of Türkoğlu, Çeliköz and Uslu (2013) in which the researchers worked with fathers in the age group 30-40 years with college degrees, professional occupations, and a maximum of 3 children between the ages of 3-6, unemployed fathers were deliberately left out of the study sample. The study explored the perceptions of the time fathers were able to spend with their children of the ages 3-6 and it was found that fathers felt that they were not spending enough time with their children due to the physical and mental fatigue they experienced as a result of their busy working hours. The present study however may have revealed higher scores in the basic care variable either because fathers spent more time at home with their children or due to the fact that their spouses were working.

According to the results of the hierarchical regression analysis performed to discover the predictability of the dependent variable of responsiveness and closeness through the information in the independent variables, as chronic illness and the number of siblings in a family increased, fathers' responsiveness and closeness scores tended to diminish.

Chronic childhood illnesses may include orthopedic problems, congenital heart disease, epilepsy, chronic kidney failure, cancer, hemophilia, asthma and other similar conditions (Erdoğan and Karaman, 2008). In research by Bayramoğlu (2009), who set out to determine the emotional state of children and adolescents diagnosed with a chronic illness, the investigator found that fathers with multiple children were more likely to display higher levels of anxiety and burnout in relation to their child with a chronic illness compared to fathers of only children.

In their sense of devotion to their children, parents go through various emotional periods when the child's health is compromised or the child develops some kind of medical condition. These periods are fraught with various emotions that include anger, hopelessness, guilt, despair, isolation, anxiety, depression and other similar states of mind. The number of siblings a child has, the parents' attitude toward the child, whether or not the parents display partiality toward one child or another or the existence of an acute or chronic illness can lead to changes and inconsistencies in the attitudes of mothers and fathers (Gültekin and Baran, 2005).

Deniz and Aral (2003) studied behavioral problems in children with and without a chronic illness and concluded that there were no significant differences between children's scores depending on the number of their siblings. Research has shown that fathers have a closer emotional interest in a sick child and feel despair when they feel they are not contributing adequately enough to the child's care and are losing control over the child's illness (Gültekin and Baran, 2005). When compared with mothers, fathers have less opportunities to help their children directly. At the same time, because of their long working hours, they receive less support and information from the health team compared to mothers. It is evident that this situation leads to the result that fathers are less involved with the problems of their child who has been diagnosed with a chronic illness (Çavuşoğlu, 1992).

Yazgan (2000) calls attention to the fact that fathers feel closer to their children when they are able to share life experiences together. Lamb (2000) reports that the more time fathers spend with their children, the more the roles fathers take on in their relationships are diversified and contribute to an enrichment of the father-child relationship. According to Güngörmüş (1990), the difference in the nature of the relationship of a child with his/her mother as opposed to the 
relationship with the father, the difference in the roles taken on within society and inside the family lead way to differences in the way fathers affect their children as compared to mothers.

\section{Conclusion}

Our study found that the number of children in a family had an effect on the discretionary involvement and responsiveness and closeness dimensions of father involvement. In other words, fathers with only one child were more likely than fathers with two or more children to participate in leisure time activities with their children, take part in games and engage in behavior that involved direct contact with the child, including hugging and kissing. Paquette, Bolte, Turcotte, Dubeau and Bouchard (2000) have found that the rate of father involvement diminishes as the number of children increases. Similarly, Mehall et al. (2009) have shown in their results that as the number of siblings increase in a family, fathers tend to show less of an interest in their babies. Şahin and Demiriz (2014) have concluded that fathers with only one child have a higher perception of their roles as father and participate more in household tasks compared to fathers with two or more children. These results point to the fact that the time fathers with two or more children are spending with their children is not adequate in terms of being involved in their children's lives as fathers.

\section{Recommendations}

In the light of these findings, more activities and settings could be staged at the pre-schools to encourage families and especially fathers to become more involved with their children. Since a positive perception of the role of fatherhood is strongly and positively associated with family involvement activities, educators may provide support in enabling fathers and other family members to develop a positive perception of fatherhood. In providing this support, to avoid the differences stemming from the variable of being a father of an only child or of more than one child, activities may be planned together with fathers to provide real-life examples that promote time management and effective leisure time management.

\section{References}

Allen, S., \& Daly, K. (2002).The Effects of Father Involvement: A Summary of the Research Evidence. Newsletter of the Father Involvement Initiative-Ontario Network, 1, 1-11. http://dx.doi.org/10.4324/9781410603500

Aral, N., Baran, G., Bulut, Ş., \& Çimen, S. (2000). Çocuk Gelişimi I. Ya-Pa Yayın Paz. San.ve Tic. A.Ş. Turan Ofset. İstanbul.

Barling, J. (1986). Fathers' Work Experiences, the Father-Child Relationship and Children's Behaviour. Journal of Occupational Behaviour, 7, 61-66. http://dx.doi.org/10.1002/job.4030070108

Baruch, G. K., \& Barnett, R. C. (1986). Role quality, multiple role involvement, and psychological well-being in midlife women. Journal of Personality and Social Psychology, 51, 578-585. http://dx.doi.org/10.1037/0022-3514.51.3.578

Bayramoğlu, M. B. (2009). Mental Ve Fiziksel Bir Nedene Bağlı Kronik Hastalık Tanısı Alan Çocuk Ve Ergenlerin Ebeveynlerinde Anksiyete, Depresyon Ve Tükenmişlik Düzeyi. T.C. Sağlık Bakanlığı Dr. Lütfi Kırdar Kartal Eğitim Ve Araştırma Hastanesi Aile Hekimliği. Yayınlanmamış Yüksek Lisans Tezi, İstanbul.

Bowlby, J. (1982). Attachment and loss: Retrospect and prospect. American Journal of Orthopsychiatry, 52(4), 664-678. http://dx.doi.org /10.1111/j.1939-0025

Cabrera, N., Fitzgerald, H. E., Bradley, R. H., \& Roggman, L. (2007). Modeling the dynamics of paternal influences on children over the life course. Applied Development Science, 11(4), 185-189. http://dx.doi.org/10.1080/10888690701762027

Carter, S. (2003). Educating Our Children Together: A Sourcebook for Effective Family -School Comminity Partnerships. http://www.directionservice.org/cadre/ educatingourchildren_01.cfm (13.11.2015)

Çatıkkaş, K. T. (2008). Okul Öncesi Ĕgitime Babaların Katılım Düzeyleri İle İlgili Değişsenlerin İncelenmesi. Yeditepe Üniversitesi Sosyal Bilimler Enstitüsü Eğitim Yönetimi ve Denetimi Yüksek Lisans Programı, Yayınlanmamış Yüksek Lisans Tezi, İstanbul.

Çavuşoğlu, H. (1992). Kronik ve Ölümcül Hastalık Kavramları İle Hematolojik ve Onkolojik Sorunu Olan Çocuk ve Hemşirelik Bakımı. Hürbilek Matbaacılık, Ankara, 15-38.

Coltrane, S. (1995). The future of fatherhood: Social, demographic and economic influence on men's family involvements. In W. Marsiglio (Ed.), Fatherhood: contemporary theory, research and social policy. (255-275). Thousand Oaks, Ca: Sage. http://dx.doi.org/10.4135/9781483327242.n13

Coverman, S. (1985). Explaining husband's participation in domestic labor. Sociological Quarterly, 26, 81-97. http://dx.doi.org/10.1111/j.1533-8525.1985.tb00217.x

Cowan, C., \& Cowan, P. (1988). Who does what when Partners become parents: implications for men, women and 
marriage. Marriage and Family Review, 12, 105-131. http://dx.doi.org/10.1300/j002v12n03_07

Deniz, Ü., \& Aral, N. (2003). Kronik hastalığı olan ve olmayan çocukların davranış problemlerinin yaş ve cinsiyete göre incelenmesi. Çăgdaş Ĕ̆itim Dergisi, 28, 37- 44.

Easterbrooks, M. A., \& Goldberg, W. A. (1985). Toddler development in the family: impact of father involvement and parenting characteristic. Child Development, 55, 740-752. http://dx.doi.org/10.1037/0012-1649.21.5.774

Erdoğan, A., \& Karaman, M. G. (2008). Kronik ve ölümcül hastalığı olan çocuk ve ergenlerde ruhsal sorunların tanınması ve yönetilmesi. Anadolu Psikiyatri Dergisi. 9, 244-252.

Fagan, J., \& Iglesias, A. (1999). Father involvement program effects on fathers, father figures and their Head Start children: A quasi-experimental study. Early Childhood Research Quarterly, 14, 243-269. http://dx.doi.org/10.1016/s0885-2006(99)00008-3

Green, S. (2001). Creating a Father Friendly Child Care Environment. Child Care Centers Connections, 10(1). http://fcs.tamu.edu/files/2015/01/fcc-10-01-father involvement.pdf (14.11.2015)

Green, S. (2003). Reaching Out to Fathers: An Examination of Staff Efforts That Lead to Greater Father Involvement in Early Childhood Programs. Early Childhood Research \& Practice, 5, 1-17

Grossman, F. K., Pollack, W., S., \& Golding, E. (1988). Fathers and children; Predicting the quality and quantity of fathering. Developmental Psychology, 24(1), 82-91. http://dx.doi.org/10.1037/0012-1649.24.1.82

Gültekin, G., \& Baran, G. (2005). Hastalık ve çocuk. Aile ve Toplum Eğitim Kültür ve Araştırma Dergisi., 8. 61-69.

Güngörmüş, O. (1990). Baba çocuk ilişkisi, Ana-Baba Okulu (2. Basım), Remzi Kitabevi. İstanbul

Gürşimşek, I., Kefi, S., \& Girgin, G. (2007). Okulöncesi Eğitime Babaların Katılım Düzeyi İle İlişkili De- ğişkenlerin İncelenmesi. Hacettepe Üniversitesi Ë̆itim Fakültesi Dergisi, 33, 181-191.

Halle, T., \& Le Menestrel, S. (2000). How do social, economic and cultural factors influence fathers' involvement with their children?. Child Trend Research Brief, 15. http://dx.doi.org/10.1037/e479992006-001

Harris, K. M., \& Morgan, S. P. (1991). Fathers, sons and daughters differential paternal involvement in parenting. Journal of Marriage and the Family, 53, 531-544. http://dx.doi.org/10.2307/352730

Hohmann, M., \& Weikart D. P. (2000). Küçük Çocukların Ĕ̆itimi. (Çev: Sibel Saltiel Kohen ve Ülfet Öğüt). Hisar Eğitim Vakfi Yayınları, 1, 433-445. http://dx.doi.org/10.1177/0192513x10388733

Ishii-Kuntz, M., Makino, K., Kato, K., \& Tsuchiya, M. (2004). Japanese fathers of preschoolers and their involvement in child care. Journal of Marriage and Family, 66, 779-791. http://dx.doi.org/10.1111/j.0022-2445.2004.00052.x

Jöreskog, K., \& Sörbom, D. (2006). Interactive LISREL 8: Structural equation modeling with the SIMPLIS command language. Chicago, IL: Scientific Software International. http://dx.doi.org/10.1207/s15328007sem1304_3

Kotaman, H. (2008). Türk Ana Babaların Çocukların Eğitim Öğretimlerine Katılım Düzeyleri. Uludă̆ Üniversitesi Eğitim Fakültesi Dergisi, 21(1), 135-149.

Kuruçırak, Ş. (2010). 4-12 aylık bebeği olan babaların, babalık rolü algısı ile bebek bakımına katılımı arasındaki ilişki. Yayınlanmamış Yüksek Lisans Tezi, Akdeniz Üniversitesi.

Lamb, M. E. (2000), Kültürler arası bakış açısı ile babanın çocuk gelişimindeki rolü ve önemi, Sempozyum Raporu, Anne Çocuk Ë̆itim Vakfi Yayın, 12, 19-32.

Levine, J. A. (1993). Involving Fathers in Head Start: A Framework for Public Policy and Program Development. Families in Society, 74, 4-19.

Levy-Shift, R., \& Israelashvili, R. (1988). Antecedents of fathering. Some further exploration. Developmental Psychology, 24, 434-440. http://dx.doi.org/10.1037/0012-1649.24.3.434

Marsiglio, W. (1991). Paternal engagement activities with minor children. Journal of Marriage and the Family, 53, 973-986.

Marsiglio, W. (1993). Contemporary scholarship on fatherhood: Culture, identity, and conduct. Journal of Family Issues, 14, 484-509. http://dx.doi.org/10.1177/019251393014004002

McBride, B. A., \& Lutz, M. A. (2004). Intervention: Changing The Nature and Extend of Father Involvement. The Role of the Father in Child Development (Edit.Michael E. Lamb).Fourth Edition. Published New York, Wiley. http://dx.doi.org/10.4324/9780203101414.ch7

McBride, B. A., Schoppe, S. J., Ho, M., \& Rane, T. (2004). Conceptualizing and Measuring Father Involvement (Edit: Randal D. Day and Michael E. Lamb). Publisher Lawrence Erlbaum Associates. http://dx.doi.org/10.1300/j002v29n04_03 
McHale, S. M., \& Huston, T. L. (1984). Men and Women as parents: sex role orientations, employment and parental roles with infants. Child Development, 55, 1349-1361. http://dx.doi.org/10.2307/1130005

Mehall, K. G., Spinrad, T. L., Eisenberg, N., \& Gaertner, B. M. (2009). Examining the relations of infant temperament and couples' marital satisfaction to mother and father involvement: a longitudinal study. Fathering, 7, 23-48. http://dx.doi.org/10.3149/fth.0701.23

Model, S. (1981). Housework by husbands; Determinants and implications. Journal of Family Issues, 2, 225-237. http://dx.doi.org/10.1177/0192513x8100200207

Palkovitz, R. (2002). Involved fathering and child development: Advancing our understanding of good fathering. C. Tamis-LaMonda, \& Cabrerra, N. (Eds.). Handbook of Father Involvement içinde (119-140), Mahwah, NJ: Lawrence Erlbaum Associates. http://dx.doi.org/10.1177/1066480702250155

Paquette, D., Bolte, C., Turcotte, G., Dubeau, D., \& Bouchard, C. (2000). A new typology of fathering: defining and associated variables. Infant \& Child Development, 9, 213-230.

http://dx.doi.org/10.1002/1522-7219(200012)9:4<213::aid-icd233>3.0.co;2-0

Parke, R. D. (1981). Fathers. Cambridge, Mass. Harvard University Press

Parke, R. D., \& O'Leary, S. (1976). Father-mother-infant interaction in the nevvborn period: Some findings, some observations, and some unresolved issues. İ K.F. Riegel and J. Meacham (Eds.), The Developing Individual in a Changing World, Vol. 2: Social and Environmental İssues. The Hague: Mouton.

Paulson, J. F., Dauber, S. E., \& Leiferman, J. A. (2010). Parental Depression, Relationship Quality, and Nonresident Father Involvement with their Infants. Journal of Family Issues, 32, 528549.

Pleck, J. H. (2010). Paternal involvement: revised conceptualization and theoretical linkages with child outcomes. M. E. Lamb, (Ed.), The Role Of The Father In Child Development, 5, 58-93, Hoboken, Wiley. http://dx.doi.org/10.1080/03004430903172335

Poyraz, M. (2007). Babaların Babalı Rolünü Algllamalarıyla Kendi Ebeveynlerinin Tutumları Arasındaki İlişkinin İncelenmesi. Gazi Üniversitesi Eğitim Bilimleri Enstitüsü, Çocuk Gelişimi ve Eğitimi Anabilim Dalında Yüksek Lisans Tezi

Radin, N. (1981). Child rearing fathers in intact families. Merrill-Palmer Quarterly, 27, 489-514.

Radin, N., \& Goldsmith, R. (1989). The involvement of selected unemployed and employed men with their children. Child Development, 60, 454-459. http://dx.doi.org/10.2307/1130989

Riley, R. W., Peterson, T. K., Moreno, M. G., \& Goode, W. W. (2000) Strengthening Participation of Fathers in Children's Learning and Development. Fathers Matther Involving Fathers in Children's Learning.A Kit for Educators and Other Professionals. USA, 442-580.

Russell, G. (1978). The father role and its relation to masculinity, femininity and androgyny. Child Development, 49, 1174-1181. http://dx.doi.org/10.2307/1128757

Şahin, F. T., \& Özbey, S. (2009). Okul Öncesi Eğitim Programlarında Uygulanan Aile K atılım Çalışmalarında Baba Katılımının Yeri ve Önemi. Aile Toplum ve Eğitim Kültür Araştırma Dergisi, 30-39.

Sahin, H., \& Demiriz, S. (2014). Beş Altı Yaşında Çocuğu Olan Babaların, Babalık Rolünü Algıllamaları İle Aile Katılım Çalışmalarını Gerçekleştirmeleri Arasındaki İlişkinin İncelenmesi. Türkiye Sosyal Araştırmalar Dergisi., 1, 273-294

Seçer Z., Çeliköz, N., \& Yaşa, S. (2007). Bazı Kişisel Özelliklerine Göre Okulöncesi Eğitim Kurumlarına Devam Eden Çocukların Babalarının Babalığa Yönelik Tutumları. Selçuk Üniversitesi Sosyal Bilimler Enstitüsü Dergisi, 18, 425-438

Sımsıkı, H., \& Şendil, G. (2014). Baba Katılım Ölçeği’nin (BAKÖ) Geliştirilmesi. Electronic Journal of Social Sciences, 49, 104-123. http://dx.doi.org/10.17755/esosder.23977

Türkoğlu, B., Çeliköz, N., \& Uslu, M. (2013). 3-6 Yaş Aralığında Çocuğu Olan Babaların Nitelikli Zaman Algılarına Dair Görüşleri. Ĕgitim ve Ö̆̆retim Araştırmaları Dergisi, 2, 54-71.

Yazgan, Y, (2000) Değişik Açılardan Babanın Çocuk Gelişimindeki Rolü Ve Önemi, Babanın Çocuk Gelişimindeki Rolü Sempozyum Raporu, İstanbul: Anne Çocuk Eğitim Vakfi, 12.

\section{$(\mathrm{Cc}) \mathrm{BY}$}

This work is licensed under a Creative Commons Attribution 3.0 License. 